\title{
A Quantitative Method for Maceration of Hydra Tissue
}

\author{
Charles N. David \\ Max-Planck-Institut für Virusforschung, 7400 Tübingen, Germany
}

Received June 22, 1972

Summary. A method is described for the maceration (dissociation) of hydra tissue into single cells. The cells have characteristic morphology such that all basic types — epithelial, gland, mucous, interstitial, nematoblast, and nerve - can be distinguished. Criteria are given for identifying each cell type by phase contrast microscopy. It is shown that maceration quantitatively recovers cells from hydra tissue.

\section{Introduction}

An understanding of morphogenetic processes in Hydra requires quantitative data on the abundance and distribution of each cell type in the animal. Obtaining such data in histological sections is difficult. We have, therefore, developed a maceration technique for rapidly and completely dissociating hydra tissue into individual cells. Each cell type is readily distinguishable in such macerations and its abundance can be determined by counting. Maceration has the additional advantage that it permits easy recognition of nerve cells and interstitial cell nests both of which can be identified only with difficulty in histological sections.

The present paper describes the maceration method, the criteria for distinguishing cell types, and the evidence that the method quantitatively recovers cells from tissue. In an accompanying paper (Bode et al., 1972) quantitative data on the cellular composition of standard hydra, regenerating hydra, and budding hydra are given. Applications of the method to the study of the proliferation and differentiation of individual cell types will be published.

\section{Materials and Methods}

Hydra attenuata were used for all experiments. For details see Bode et al. (1972).

Maceration. Tissue was macerated in a solution containing glycerin:glacial acetic acid: water $(1: 1: 13)$ at room temperature. This is a modification of Schneider's (1890) procedure which consisted of maceration in a solution containing fixative. Pieces of hydra tissue were placed in maceration solution (about $0.1 \mathrm{ml}$ per hydra) in disposable polyethylene test tubes $(7 \times 50 \mathrm{~mm}$ or $15 \times 50 \mathrm{~mm})$, soaked for a few minutes and shaken gently until the pieces dissociated to give a suspension of single cells. Tentacles, hypostome, and basal disk required longer soaking and more vigorous shaking to dissociate. Very small pieces of tissue were best dissociated by teasing the tissue apart in drop of maceration solution directly on a microscope slide. When tissue pieces were completely dissociated, the resulting cell suspension was fixed by addition of 0.1 volume of $20 \%$ formaldehyde and/or 0.1 volume of $1 \% \mathrm{OsO}_{4}$.

Preparations for Cell Counting. Fixed cell suspensions were mixed with a drop of detergent (e.g. $1 \%$ Tween 80 ) and spread on gelatin-coated microscope slides to dry. For accurate cell distributions it was important to keep the drying slides absolutely level, otherwise nerve cells accumulated on that part of the slide which dried last. To examine cells a drop of water and a cover slip were placed on the slide and phase contrast optics were used (20x and $40 \times$ objectives). 
Cell titers were determined in a Schilling cell counter $(0.1 \mathrm{~mm}$ depth). The absolute number of cells in tissue pieces or whole animals was determined by dissociation and titering in a known volume of maceration solution.

$D N A$ Determinations. Hydra tissue was dissociated in maceration solution and the cell titer determined. Aliquots of the solution were precipitated with 1 volume of $20 \%$ trichloroacetic acid (TCA) in an ice bath. The precipitate was collected by centrifugation $(4000 \mathrm{rpm}$ $10 \mathrm{~min}$ ), washed with $5 \%$ TCA and extracted with $1 \mathrm{ml} 100 \%$ ethanol at $60^{\circ} \mathrm{C}$ for $10 \mathrm{~min}$. The precipitate was collected again by centrifugation and dried at $50^{\circ} \mathrm{C}$ under vacuum.

DNA was determined on the precipitates with the fluorescence method of Kissane and Robbins (1958) using the reagent diaminobenzoic acid. 3,5 diaminobenzoic acid (p.A.) was obtained from Fluka, Switzerland. It was dissolved in distilled water at $0.4 \mathrm{~g} / \mathrm{ml}$ and extracted 2-3 times with $10 \mathrm{mg}$ active charcoal before use. $0.1 \mathrm{ml}$ of the diaminobenzoic acid reagent was added to each precipitated sample and the samples incubated for $45 \mathrm{~min}$ at $60^{\circ} \mathrm{C}$. Following incubation the samples were diluted with $3 \mathrm{~mL} 1 \mathrm{~N} \mathrm{HCl}$ and fluorescence measured at $515 \mathrm{~m} \mu$ (excitation at $365 \mathrm{~m} \mu$ ). Calf thymus DNA was used as a standard. The concentration of the standard DNA solutions was determined spectrophotometrically $(1 \mu \mathrm{g}$ DNA $/ \mathrm{ml}=$ $0.02 \mathrm{OD}_{260}$ ). The fluorescence was linear over a range of $0.5-5.0 \mu \mathrm{g}$ DNA per sample under these conditions. As a control for the specificity of the reaction, the precipitates were pretreated with DNase $(100 \mu \mathrm{g} / \mathrm{ml}, 6$ hours $)$. Greater than $95 \%$ of the fluorescence was removed from samples by this treatment.

\section{Results}

\section{Tissue Maceration and the Identification of Cell Types}

Parts of hydra or whole animals are dissociated to single cells in maceration solution as described in Methods. The dissociated cells (Fig. 1) have characteristic morphology which allows easy identification of all basic cell types. A description of the cell types follows including a definition of the criteria used to identify them with phase contrast opties and their relationship to cell types identified by other investigators (see Kanaev, 1952; Lentz, 1966 for review).

Epithelial Cells. Epithelio-muscular and digestive cells form the two epithelial layers - ectoderm and endoderm, respectively — which are the basic structural elements of hydra tissue and within which the other cell types are embedded. Epithelial cells are by far the largest cells in hydra tissue and thus are easily distinguished in maceration preparations (Figs. 1 and 2).

Ectodermal epithelio-muscular cells (Fig. $2 \mathrm{~b}$ ) are large cuboidal or columnar cells $\left(45-60 \mu\right.$ long, $20-40 \mu$ wide) ${ }^{1}$ bearing two long muscle processes at their proximal ${ }^{2}$ end which give the cells the appearance of a "tophat". They are filled with extensive intracellular spaces or vacuoles separated by thin strands of cytoplasm. In the center or to the proximal end of the cell there is a large nucleus $(\mathbf{1 0 - 1 4} \mu)$ with 1 or 2 conspicuous nucleoli.

The basic epithelial cell structure is modified in the ectoderm of the tentacles and basal disk to give battery cells and glandular epithelial cells, respectively. Battery cells (Fig. 2 d) are shorter $(20-30 \mu)$ and wider $(40-60 \mu)$ than epithelial cells of the body column. They are filled with 10-20 nematocytes. Glandular epithelial cells (Fig. 2c) of the basal disk are characterized by their long columnar structure $(60-80 \mu$ long; $10-15 \mu$ wide), relatively short muscle processes, and cytoplasm filled with granular material.

1 Cell dimensions measured in maceration preparations are about $30 \%$ larger than cell dimensions observed in histological sections of formaldehyde-fixed hydra due to the swelling effect of acetic acid in maceration solution.

2 The ends of cells are proximal or distal relative to the mesoglea. 


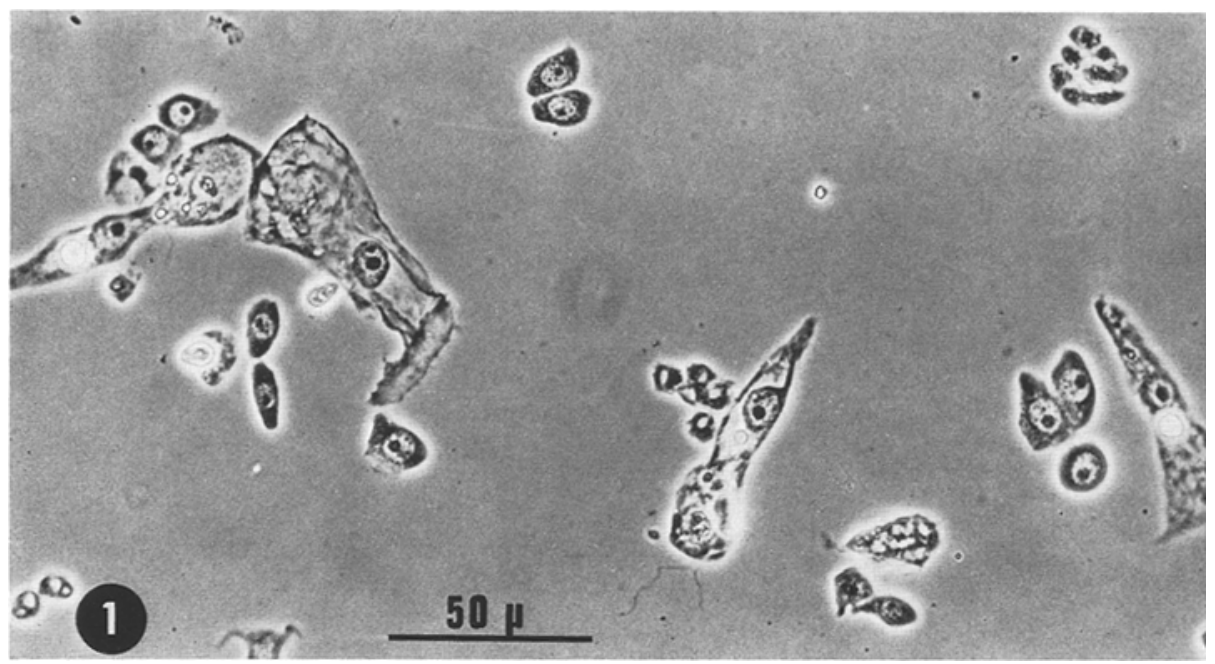

Fig. 1. Maceration preparation at low magnification with phase contrast optics showing: 2 single big I-cells, 5 big I-cell nests of 2, 1 epithelio-muscular cell, 3 digestive cells, 1 gland cell, 1 differentiated stenothele, 1 differentiated desmoneme, 7 developing desmonemes, and 1 little I-cell nest of $8 . \times 400$
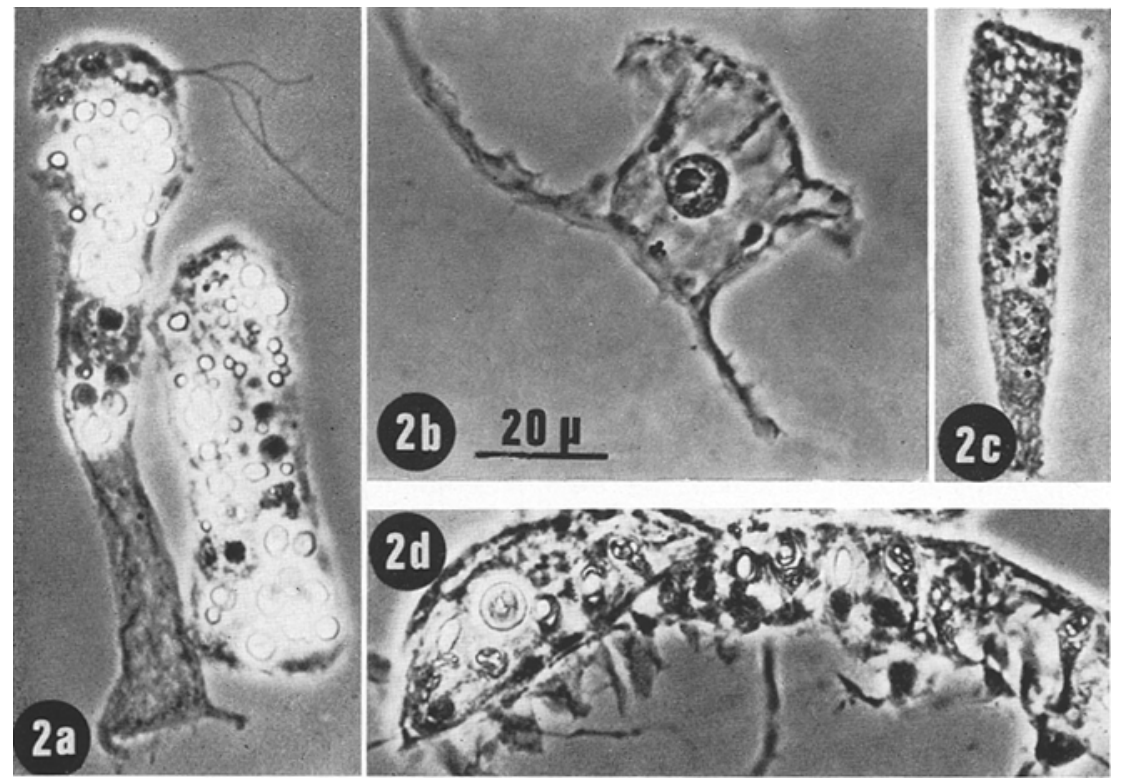

Fig. 2a-d. Epithelial cells. a) Digestive cells, b) epithelio-muscular cell,c) glandular epithelial cell from basal disk, d) 2 battery cells containing nematocytes (view of distal surface-left, lateral surface-right). All photographs $\times 590$

Digestive cells (Fig. 2 a) are tall, columnar cells (80-130 $\mu$ long; 15-25 $\mu$ wide). They have short muscle processes at the proximal end and several flagella at the distal end. In well fed hydra the distal half of the cell is filled with a heterogeneous 


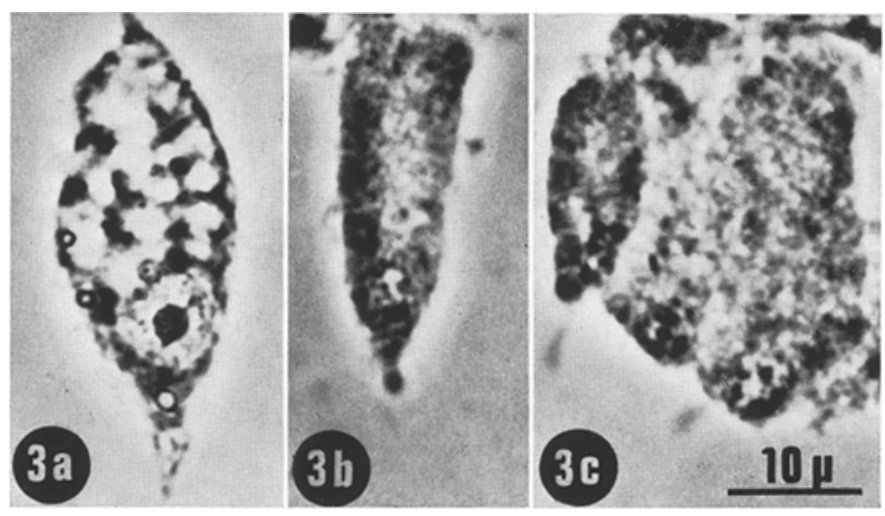

Fig. $3 a-c$. Gland cells. a) Gland cell with large secretory granules, b) mucous cell from hypostome (the cytoplasm is filled with secretory material which almost obscures the nucleus at the lower end of the cell), c) 3 mucous cells stuck together in maceration preparation. All photographs $\times 1180$

collection of food vacuoles and granules. The granules are highly refractile and thus conspicuously colored in phase contrast optics. A large nucleus $(10-14 \mu)$ with nucleolus is located near the center of the cell while the proximal end of the cell usually contains a large vacuole surrounded by a thin rim of cytoplasm. In the tentacles and peduncle-basal disk regions endodermal epithelial cells have many fewer inclusions and a larger intra-cellular vacuole.

Gland Cells (Secretory Cells). Gland cells occur in hydra between the epithelial cells of the endoderm. At least two types of gland cells have been described: the enzyme-(zymogen) secreting type (secretory granules $2-4 \mu$ ) usually referred to as gland cell and the mucus-secreting type (secretory granules $<1 \mu$ ) usually referred to as mucous cell (Burnett, 1959). The former occurs principally in the gastric region; the latter occurs chiefly in the hypostome.

In maceration preparations examined with phase contrast optics two types of secretory cells are distinguishable based on the size of the secretory granules in the cytoplasm. Gland cells (Fig. 3a) are oval or teardrop in form (25-35 $\mu$ long and $15 \mu$ wide) and have 1-2 flagella at the distal end. The cytoplasm is filled with large granules $(2-4 \mu)$ which appear pale in phase contrast opties. The nucleus $(7-9 \mu)$, usually with a nucleolus, is located in the proximal end of the cell sometimes partially obscured by secretory granules.

Hypostomal mucous cells (Fig. $3 \mathrm{~b})$ are long $(15-30 \mu)$ and thin $(7-9 \mu)$ with one end slightly flared out giving the cell an almost rectangular appearance. The cytoplasm has a foamy appearance due to densely packed granules which cannot be resolved in phase contrast optics. A small nucleus $(5 \mu)$ is often barely distinguishable in the granular cytoplasm at the proximal end. At the distal end the cell has 1-2 flagella. In maceration preparations mucous cells from the hypostome characteristically stick together in clumps (Fig. 3c).

Interstitial Cells ( $I$-cells). Interstitial cells are the precursors for at least two major cell types in hydra, nerve cells and nematoblasts (Lentz, 1966). They occur in large numbers in the ectoderm in clusters (nests) of 2 to 16 cells (occasion- 
Table 1. Occurrence of big and little interstitial cells in nests

\begin{tabular}{lccccc}
\hline Number of cells in nest & 1 & 2 & 3 & 4 & $>4$ \\
\hline Percent of big I-cells & 12 & 55 & 4 & 24 & 5 \\
\hline & & & & & \\
\hline Number of cells in nest & 1,2 & & 3,4 & $5,6,7$ & $8,>8$ \\
\hline Percent of little I-cells & 9 & 6 & 20 & 65 \\
\hline
\end{tabular}

The data are the average from several independent experiments in which at least 5000 cells were counted. In very gently prepared macerations, there are fewer little I-cells in small nests but otherwise a similar distribution is found.

ally 32) located in spaces between epithelio-muscular cells (Lehn, 1951). A much smaller number of interstitial cells is found in the endoderm (Brien and ReniersDecoen, 1955).

In maceration preparations interstitial cells can be divided into two classes distinguishable on the basis of their size and morphology. These classes have been named big interstitial cells and little interstitial cells. Big I-cells (Fig. 4a, b, c) are $12-20 \mu$ in size and angular in shape. They have a large nucleus $(8-12 \mu)$ with a conspicuous nucleolus, very similar to epithelial cell nuclei. The cytoplasm is uniform and granular. Little I-cells (Fig. 4d, e) are 7-12 $\mu$ in size. They contain a small nucleus $(6-7 \mu)$ without nucleolus, which is often difficult to distinguish from the thin ring of granular cytoplasm surrounding it.

Interstitial cells occur in maceration preparations primarily in clusters (Fig. $4 \mathrm{a}-\mathrm{e})$ similar to the nests observed in whole animals. The occurrence of I-cells in clusters is probably the result of the presence of cytoplasmic bridges between the cells (Slautterback and Fawcett, 1959) which are not susceptible to dissociation by the maceration solution. Table 1 indicates that big I-cells occur most frequently as pairs, but also as single cells and in nests of 4 . They occur rarely in nests of more than 4 cells. In contrast, $60-70 \%$ of all little I-cells occur in nests of 8 or more cells. The strong correlation between the morphology of I-cells and nest size in which they occur suggests that the clusters are not artefacts of maceration. The extent to which big and little I-cells are nematoblasts, in which the differentiating nematocyst capsule has not yet become visible, will be described elsewhere (David, in preparation).

Nematocytes. Hydra attenuata contains 4 types of nematocytes: stenotheles, desmonemes, steroline isorhizas and streptoline isorhizas. The morphology of the nematocyst capsule in each cell type has been extensively described elsewhere (Lentz, 1966). Nematocytes, each with a mature nematocyst capsule, are mounted mainly in specialized ectodermal epithelial cells (battery cells) in the tentacles and less frequently in ectodermal epithelial cells of the body column. In maceration preparations nematocytes occur primarily in battery cells dissociated from the tentacles (Fig. 2d).

Nematoblasts. Nematoblasts are the differentiating precursor cells to the nematocytes which fill the battery cells of the tentacles. During differentiation of the nematocyst capsule, nematoblasts occur in nests in the ectoderm of the 

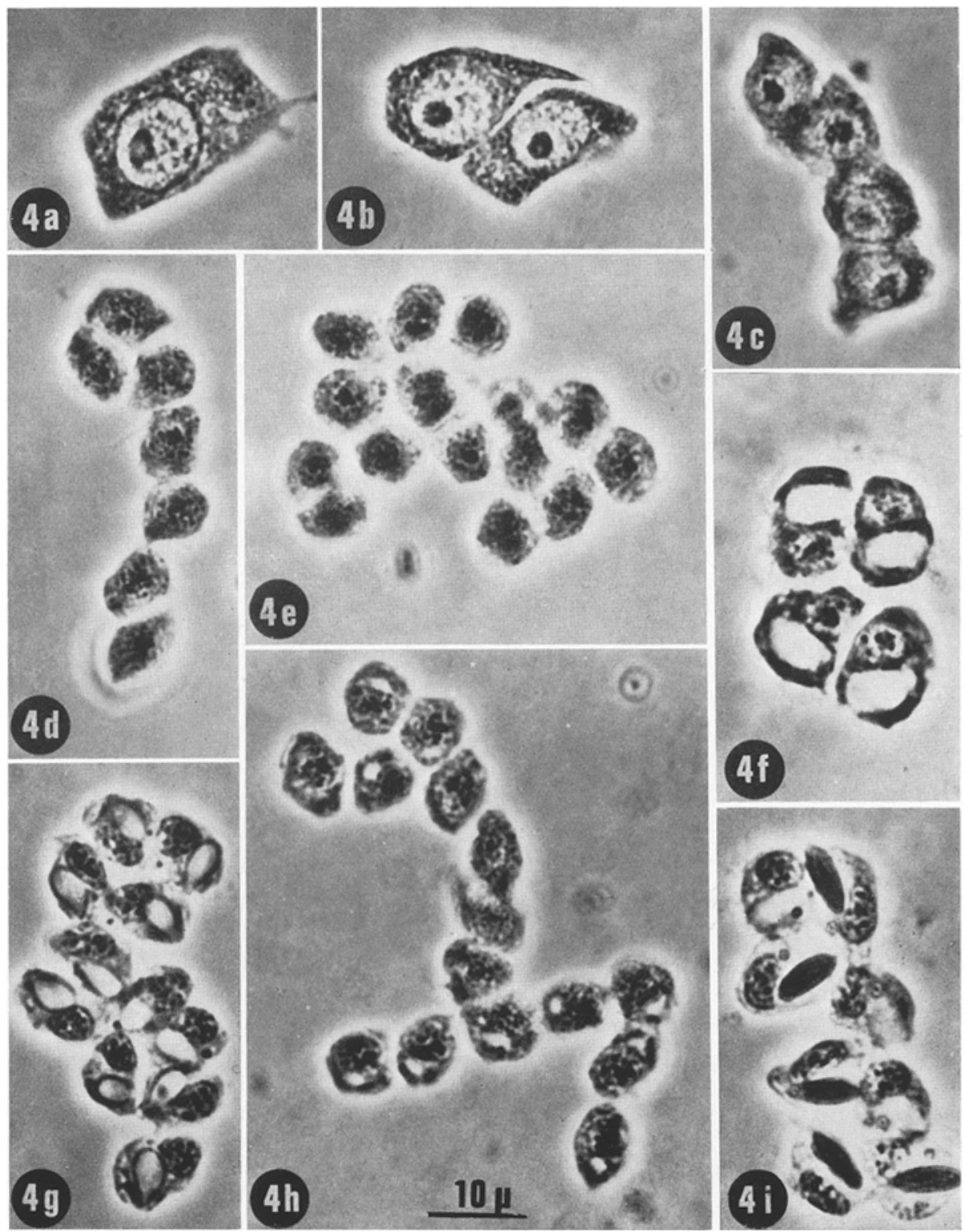

Fig. $4 a-i$. Interstitial cells and nematoblasts: a) Single big I-cell, b) and c) nests of 2 and 4 big I-cells, d) and e) nests of 8 and 16 little I-cells (in both nests one cell is out of focus), $\mathrm{f}$ ) nest of 4 developing nematoblasts (probably stenotheles), g) nest of 11 desmoneme nematoblasts, h) nest of 15 developing nematoblasts (probably desmonemes), i) nest of 8 isorhiza nematoblasts (several nematocyst capsules have fallen out of the nematoblasts). Note the progressive reduction in nuclear dimensions from big I-cells (nucleus with nucleolus) to mature nematoblasts (nucleus with condensed chromatin and no nucleolus). All photographs $\times 1180$ 
hydra body column (Lehn, 1951; Rich and Tardent, 1969). Following completion of the capsule, the nests break up into single cells which migrate through the ectoderm to the tentacles (Campbell, 1967).

In maceration preparations, nematoblasts occur both as single cells and in nests. (To what extent single nematoblasts are migrating cells or cells broken from nests during maceration cannot be decided with the present method.) In size and morphology nematoblasts are similar to interstitial cells but are distinguishable as a distinct cell type by the presence of a developing nematocyst capsule in the cytoplasm (Fig. 4f, g, h, i). In phase contrast optics the developing capsule appears first as a pale object or droplet in the cytoplasm which grows larger and acquires in later stages the characteristic size and shape of one of the 4 types of nematocyst capsule. The nuclei of nematoblasts having well differentiated nematocyst capsules are small (4-5 $\mu$ ) containing condensed chromatin and no nucleolus (Fig. $4 \mathrm{~g}$, i). The nuclei of developing nematoblasts are similar to I-cell nuclei (Fig. 4f, h). In general, the stenothele nematoblasts appear to develop from nests of big interstitial cells while the desmoneme nematoblasts develop most frequently from nests of little interstitial cells.

Nerve Cells. Three types of nerve cells have been identified in hydra: ganglion cells, sensory cells (Schneider, 1890; Hadzi, 1909; McConnell, 1932), and neurosecretory cells (Lentz and Barrnett, 1965). Neurosecretory cells identified in electron microscopic preparations are, in the light microscope, morphologically so similar to ganglion cells that we have not attempted to distinguish them as a separate type.

Ganglion cells (Fig. 5a, b, d) are the most common type of nerve cells in hydra occurring throughout the body column and tentacles. Ganglion cells are characterized by a small cell body $(8-12 \mu)$ and long thin cytoplasmic processes (30 to $200 \mu$ ). Such cells have 2 (bipolar) or more (multipolar) processes many of which are branched or interrupted by nodules. The nucleus is small $(5-7 \mu)$ and filled with highly condensed chromatin often granular in appearance. A nucleolus is rarely present. The cytoplasm is uniformly granular. Ganglion cells in the hypostome and tentacles generally have less cytoplasm surrounding the nucleus than ganglion cells of the peduncle-basal disk region which are distinctly "fleshy" in appearance (compare Fig. $5 \mathrm{a}$ and $5 \mathrm{~b}$ ). Although some ganglion cells in maceration preparations appear to have dense droplets in their cytoplasm, the relationship of these droplets to neurosecretory granules described by Lentz and Barrnett (1965) is not clear.

Sensory cells (Fig. 5c), although less numerous than ganglion cells, also occur throughout hydra tissue. They are characterized by a small, usually narrow cell body $(15 \mu)$ with a long thin cytoplasmic process at one end similar to that of ganglion cells. At the other end sensory cells have a short cytoplasmic extension ending in a bulbous thickening. Sensory cell nuclei are oblong $(7-9 \mu)$ and contain condensed chromatin similar to ganglion cell nuclei. The nucleus is surrounded by small amounts of granular cytoplasm.

\section{Quantitative Recovery of Cells Following Tissue Maceration}

The quantitative recovery of cells following tissue maceration was tested: (1) by comparing the DNA content and the cell titer of a maceration preparation 


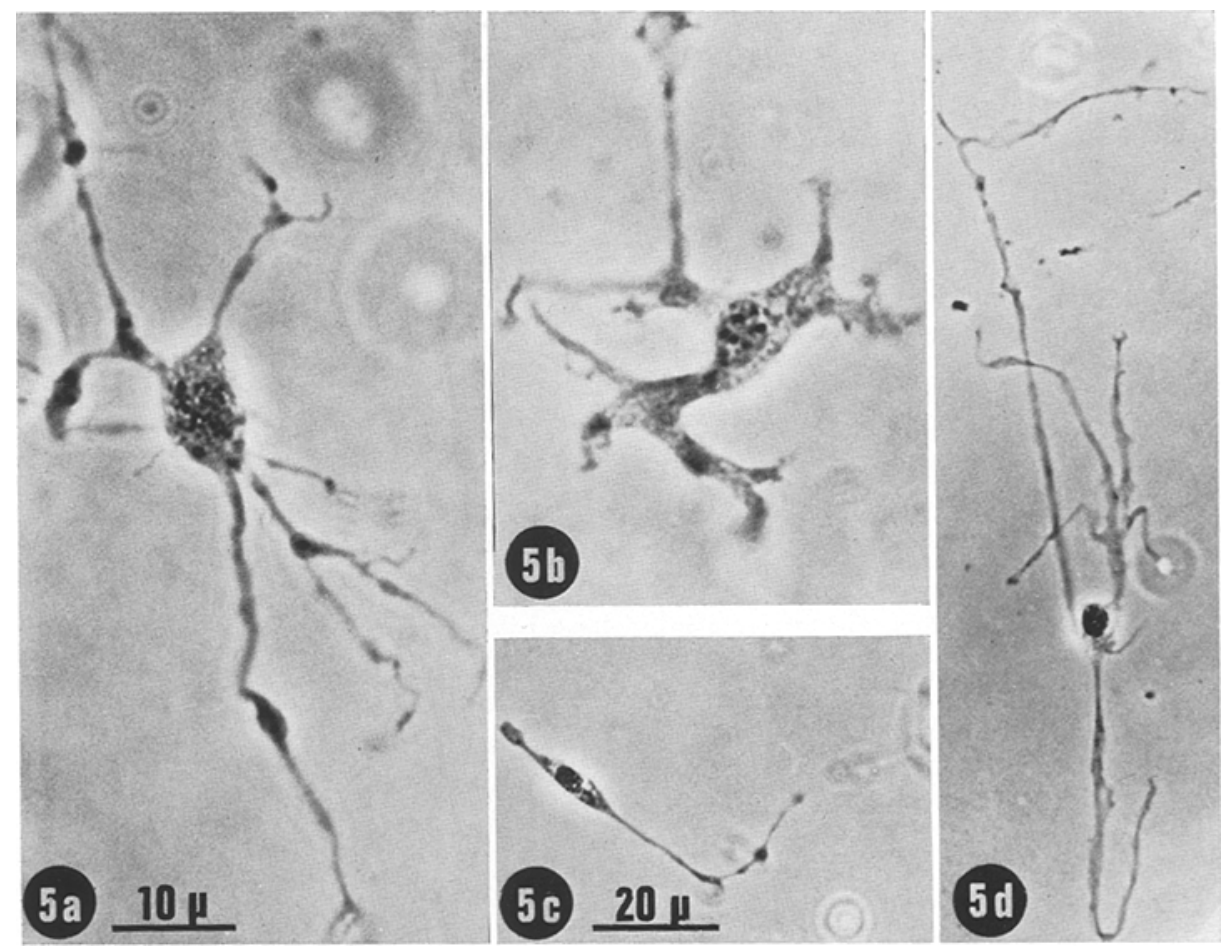

Fig. 5a-d. Nerve cells. a) Ganglion cell from hypostomal region, b) ganglion cell from basal disk, c) sensory cell, d) ganglion cell from gastric region with long process $(200 \mu)$. a) and b) $\times 1180$. c) and d) $\times 590$

(if maceration destroys cells, there will be a discrepancy between DNA assayed and the titer of countable cells) and (2) by determining the stability of the total cell titer and of individual cell types in maceration preparations over a period of several hours.

Table 2 gives the DNA content and the cell titer of three independent maceration preparations. The DNA content per cell averaged over all cell types in hydra is about $4 \times 10^{-12} \mathrm{~g}$ (David, unpublished). Using this average DNA content per cell the expected cell titer has been calculated for the maceration preparations in Table 2. The results indicate that the recovery of cells following tissue maceration is very high and may be $100 \%$.

The results in Table 3 indicate that the total cell titer and the distribution of cell types are stable over many hours in maceration solution. There is no suggestion of either selective or non-selective cell destruction. Furthermore, all cell types, which have been identified in histological sections of hydra, are also present in macerations. Considered together, the data on the recovery and stability of cells in maceration preparations indicate that the maceration of hydra tissue is a quantitative procedure for the assay of cell types. 
Table 2. Cell recovery in maceration preparations

\begin{tabular}{llll}
\hline $\begin{array}{l}\text { Prepa- } \\
\text { ration } \\
\text { No. }\end{array}$ & $\mu g$ DNA/sample & \multicolumn{2}{l}{ Cell titer/sample } \\
\cline { 3 - 4 } & & Assayed & Calculated $^{\mathrm{a}}$ \\
\hline 1 & 2.3 & $5.9 \times 10^{5}$ & $5.7 \times 10^{5}$ \\
2 & 2.2 & $6.0 \times 10^{5}$ & $5.5 \times 10^{5}$ \\
3 & 2.4 & $6.7 \times 10^{5}$ & $6.0 \times 10^{5}$ \\
\hline
\end{tabular}

Pieces of hydra tissue were macerated. The DNA content and cell titer were determined on samples taken from the suspension of macerated cells.

a Cell titer was calculated from the measured $\mu \mathrm{g}$ DNA/sample using a nuclear DNA content of $4 \times 10^{-12} \mathrm{~g} /$ cell. This value is a weighted average based on the distribution of cell types in hydra and the average nuclear DNA content of each cell type (David, unpublished).

Table 3. Stability of cells in maceration preparations

\begin{tabular}{llllllll}
\hline $\begin{array}{l}\text { Time } \\
\text { (hours) }\end{array}$ & $\begin{array}{l}\text { Total } \\
\text { cells } / \mathrm{ml}\end{array}$ & \multicolumn{6}{c}{ Cell type distribution (in percent of total) } \\
\cline { 3 - 7 } & $\begin{array}{l}\text { Epi- } \\
\text { thelial }\end{array}$ & $\begin{array}{l}\text { Big } \\
\text { inter- } \\
\text { stitial }\end{array}$ & $\begin{array}{l}\text { Little } \\
\text { inter- } \\
\text { stitial }\end{array}$ & $\begin{array}{l}\text { Nemato- } \\
\text { blast }\end{array}$ & Nerve & Gland \\
\hline 1 & $9.1 \times 10^{5}$ & 24 & 22 & 15 & 31 & 3 & 4 \\
4 & $9.2 \times 10^{5}$ & 21 & 25 & 11 & 35 & 3 & 5 \\
7 & $9.6 \times 10^{5}$ & 19 & 23 & 15 & 37 & 3 & 4 \\
24 & $9.1 \times 10^{5}$ & 21 & 21 & 20 & 30 & 3 & 4 \\
\hline
\end{tabular}

Pieces of hydra tissue were soaked without shaking in maceration solution for the times indicated. Total cells $/ \mathrm{ml}$ was determined in a Schilling cell counter. The cell type distribution was determined after spreading and drying the preparation on a microscope slide. At least 1000 cells were counted at each sample time.

\section{Discussion}

A method has been described for the quantitative dissociation of hydra tissue into single cells. The cells retain characteristic morphology which allows the easy identification, using phase contrast optics, of the basic cell types and a number of their derivatives: epithelio-muscular cells, digestive cells, battery cells, gland cells, mucous cells, interstitial cells (2 classes), nematoblasts (4 types), nematocytes ( 4 types), and nerve cells ( 2 types).

The maceration technique has several advantages over standard histological sections: (1) in providing single cell suspensions good for statistical analysis of the cellular composition of tissue, (2) in speed and ease of preparation which make kinetic experiments on cellular turnover possible, (3) in providing single cells suitable for autoradiography and quantitative determination of intracellular components by microspectrophotometry. The present maceration technique can be combined with histochemical staining, allowing a more refined characterization of particular cell types. The major disadvantage of the maceration technique is the loss of tissue architecture and the structural relationship of cells to each other, although microsurgery can partially relieve this drawback of the method. 
Acknowledgements. This research was performed during tenure of a Helen Hay Whitney Postdoctoral Fellowship.

\section{References}

Bode, H., Berking, S., David, C. N., Gierer, A., Schaller, H., Trenkner, E.: Quantitative analysis of cell types during growth and morphogenesis in Hydra. Wilhelm Roux' Archiv 171, 269 (1972).

Brien, P., Reniers-Decoen, M.: La signification des cellules interstitielles des hydres d'eau douce et le problème de la róserve embryonnaire. Bull. biol. France Belg. 89, 258-325 (1955).

Burnett, A. L.: Histophysiology of growth in Hydra. J. exp. Zool. 140, 281-342 (1959).

Campbell, R.: Tissue dynamies of steady state growth in Hydra littoralis. III. Behavior of specific cell types during tissue movements. J. exp. Zool. 164, 379-393 (1967).

Hadzi, J.: Utber das Nervensystem von Hydra. Arb. zool. Inst. Univ. Wien 17, 225-269 (1909).

Kanaev, J. J.: Hydra. Essays on the biology of fresh water polyps. Originally published by Soviet Academy of Sciences, Moscow; edit. by H. M. Lenhoff (1952).

Kissane, J. M., Robbins, E.: The fluorometric measurement of DNA in animal tissues. J. biol. Chem. 283, 184-188 (1958).

Lehn, H.: Teilungsfolgen und Determination von I-Zellen für die Cnidenbildung bei Hydra. Z. Naturforsch. 6b, 388-391 (1951).

Lentz, T. L.: The cell biology of Hydra, p. 199. Amsterdam: North-Holland 1966.

Lentz, T. L., Barrnett, R. J.: Fine structure of the nervous system of Hydra. Amer. Zool. 5, 341-356 (1965).

McConnell, C. A.: The development of the ectodermal nerve net in the buds of hydra. Quart. J. micr. Sci. 75, 495-509 (1932).

Rich, F., Tardent, P.: Untersuchung zur Nematocyten-Differenzierung bei Hydra attenuata. Rev. suisse Zool. 76, 779-787 (1969).

Schneider, K. C.: Histologie von Hydra fusca mit besonderer Berücksichtigung des Nervensystems der Hydropolypen. Arch. mikr. Anat. 35, 321-379 (1890).

Slautterback, D. B., Fawcett, D. W.: The development of the cnidoblasts of hydra. An electron microscope study of cell differentiation. J. biophys. biochem. Cytol. 5, 441-452 (1959).

Charles N. David

Max-Planck-Institut für Virusforschung

D-7400 Tübingen

Spemannstr. 35

Federal Republic of Germany 